\title{
A Look at Well known Perception of Patron About Emblem Name and Advertising Technique and The Way it Impacts Their Buying Choice, at Rachna Woolen Mill, Ludhiana (Punjab)
}

\author{
Gowtha Aasirvad Kumar,A. Ravikumar, D. Raviteja
}

\begin{abstract}
Emblem photo and industrial play a vital feature to beautify up any commercial enterprise ordinary performance as emblem image is an implied device which can clearly trade humans's searching for behaviors and business is behaving as a using pressure for any enterprise because it's an effective supply to supply your message and stay in customer's thoughts. The motive of this take a look at is to take a look at the effect of brand photograph and advertisement on consumer shopping for conduct in the majority at Gujranwala city. Questionnaire survey have become used to gather the records by using the usage of using non opportunity accessible sampling approach. A sample of two hundred questionnaires turn out to be used in which a hundred 75 responses had been collected inside the length of one month. Findings display that brand photograph and business have strong great have an effect on and large relationship with consumer purchasing for conduct. humans recognize the emblem image with powerful mindset. take a look at depicted that young adults in Gujranwala are extra privy to their social reputation simply so they decide upon branded products and advertisement impacts their purchaser searching for behavior genuinely. inside the final of article limitations of research, implications and recommendations for similarly studies also blanketed. [2 ],[ 4],[6]

Keywords : Brand image, Advertisement, Consumer Buying Behavior.
\end{abstract}

\section{INTRODUCTION}

A check on preservation manage In a emblem this is broadly diagnosed within the marketplace acquires emblem reputation. whilst logo reputation builds up to some extent in which a logo enjoys a important mass of effective sentiment in the marketplace, it's miles stated to have finished brand franchise. One aim in logo recognition is the identification of a emblem with out the selection of the organisation present. as an example, Disney has been a success at branding with their particular script font (before everything created for Walt Disney's "signature" brand), which it used within the logo for pass.com customers can also appearance on branding as an important fee added element of services or products, as it often serves to denote a certain appealing wonderful or

\section{Revised Manuscript Received on July 22, 2019}

Gowtham Aasirvad Kumar, Department of MBA, Bharath Institute of kgowthamaashirwad123@gmail.com

Dr.A.Ravikumar, Department of MBA, Bharath Institute of Higher Education and Research, Tamilnadu, India. Email: ravikumar.th@bharathuniv.ac.in

D.Raviteja, Department of THM, Bharath Institute of Higher Education Higher Education and Research, Tamilnadu, India. Email: and Research, Tamilnadu, India. Email: ravitejamba @bharathuniv.ac.in

function (see moreover brand promise). From the mind-set of brand proprietors, branded products or services moreover command higher charges. in which merchandise resemble each unique, but sincerely one in each of the products has no related branding (alongside facet a common, hold-branded product), people can also moreover often pick out out the extra highly-priced branded product at the idea of the tremendous of the brand or the recognition of the brand owner.. [1],[3],[5]

\section{BRAND AWARENESS}

Brand attention refers to customers' capability to don't forget and apprehend the logo below super situations and link to the emblem name, emblem, jingles and so forth to immoderate high-quality associations in reminiscence. It lets in the customers to apprehend to which services or products elegance the proper emblem belongs and what services and products are offered below the logo name. [7],[ 9], ,[11]It moreover guarantees that clients understand which in their desires are glad with the useful resource of the brand via its merchandise (Keller). brand interest is of important importance for the reason that clients will no longer endure in mind your logo if they'll be not aware of it. 'brand love', or love of a emblem, is an emerging term encompassing the perceived price of the logo photograph. brand love degrees are measured via social media posts about a emblem, or tweets on net web web sites which incorporates Twitter. becoming a Face e-book fan of a selected brand is also a length of the amount of 'logo love'. [8],[ 10], ,[12]

\section{BRAND PROMISE}

The marketer and owner of the brand has a imaginative and prescient of what the logo need to be and do for the purchasers. brand promise is what a selected brand stands for (and has stood for within the past). It has its roots from the identity that it profits over a time frame. usually, emblem promise is an characteristic commonplace to 'determine' producers. Herein, the emblem can also moreover appreciably stand for high-quality, average performance, trust, or faux ensures. however, the extensions, or the manufacturers under the parent logo umbrella, can also stand for my part for a particular trait which it has delivered over time,

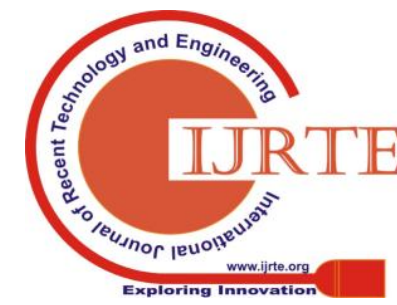


A Look at Wellknown Perception of Patron About Emblem Name and Advertising Technique and The Way It Impacts Their Buying Choice, at Rachna Woolen Mill, Ludhiana (Punjab)

for example, 'the first-rate glowing teeth', or 'the relied on economic corporation to monetary group with for hundreds of years', et al. [13], [15] ,[ 17]

\section{A. Global brand}

A international brand is one this is appeared to mirror the equal set of values spherical the area. worldwide manufacturers flow past their origins and create sturdy enduring relationships with customers all through international locations and cultures. they'll be producers presented in international markets. Examples of worldwide manufacturers consist of Face e-book, Apple, Coca-Cola, McDonald's, credit card, hole and Sony. those manufacturers are used to sell the same product in some unspecified time in the destiny of a couple of markets and can be considered a hit to the extent that the associated merchandise are without difficulty recognizable with the beneficial aid of the severa set of clients. [14],[16], [18]

\section{OBJECTIVES OF THE STUDY}

The main purpose of this undertaking become to look at the market phase of readymade garment for RACHNA growth.

- It's far helpful for advertising department to recognise which incentive is greater effective to enhance the sales.

- To know the non-public perspectives of humans Concerning options to Readymade garments.

- To look at the impact of logo name on buying selection.

- To have a look at the influence of advertising and marketing approach on buying decision.

- Discover aspect influencing the humans at the time of buying Garment/material. best, durability, variety, fee availability logo[19],[21],[23]

\section{RESEARCH METHODOLOGY}

Research refers to a search for understanding. it's miles a scientific technique of amassing and recording the statistics inside the form of numerical records relevant to the formulated trouble and arriving at certain conclusions over the hassle based totally on accumulated statistics. [20],[22], [24] as a result components of the trouble is the primary and principal step in the research technique observed by means of the collection, recording, tabulation and evaluation and drawing the conclusions. The hassle formulation begins with defining the hassle or quantity of problems inside the useful vicinity. To hit upon the useful location and find the precise problem is maximum crucial a part of any studies as the entire research is based at the hassle.in keeping with Clifford Woody research incorporates defining and redefining troubles, formulating hypothesis or advised answers: gathering, organizing and evaluating information: making deductions and reaching conclusions: and at closing cautiously testing the conclusions to decide whether they healthy the formulating speculation.Studies may be defined as "the manipulation of things, ideas or symbols for the reason of generalizing to extend, correct or verify information, whether that knowledge aids in creation of concept or inside the exercise of an art"

In brief, the search for knowledge via goal and systematic method of finding method to a problem is studies.

[25],[27],[29]

\section{DRAFTING QUESTIONNAIRE}

The questionnaire is considered because the maximum critical component in a survey operation. hence it have to be carefully constructed. dependent questionnaire include best constant opportunity questions. Such kind of questionnaire is less expensive to analysis and easy to administer

\section{* INTERPRETATION \& ANALYSIS OF DATA} Have you heard about RACHNA WOOLEN MILL?

Table:1

\begin{tabular}{|l|l|}
\hline YES & $65 \%$ \\
\hline NO & $35 \%$ \\
\hline
\end{tabular}

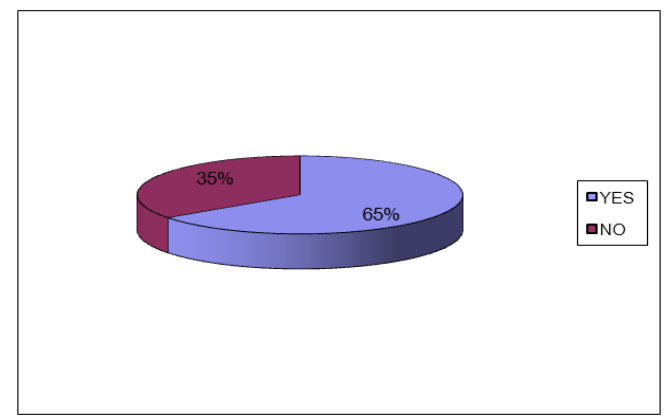

Fig:1

INTERPRETATION: The above chart show that RACHNA is well known brand \& it is known by more than two third of people in two cities.

\section{(1) From where you like to buy RACHNA GARMENT?}

Table:2

\begin{tabular}{|l|l|}
\hline $\begin{array}{l}\text { Branded } \\
\text { Showroom }\end{array}$ & $5 \%$ \\
\hline Retail Shop & $40 \%$ \\
\hline Shopping Ma11s & $10 \%$ \\
\hline Others & $45 \%$ \\
\hline
\end{tabular}

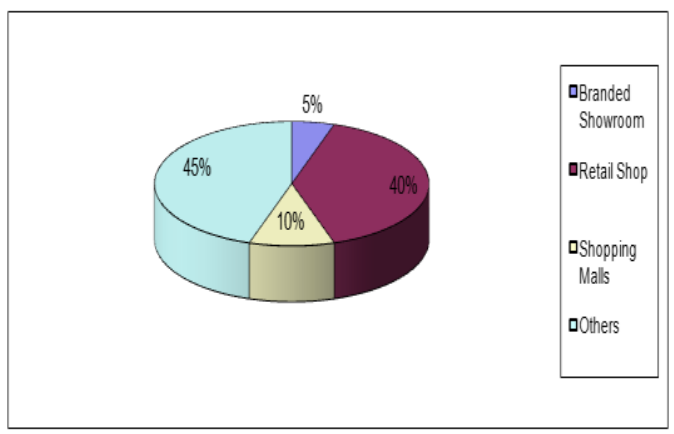

Fig:2 
INTERPRETATION: Though people are more conscious about quality and branded clothes but not conscious in the fabrics. As the graph indicates that retail shop are most prefer by customer than other. [26],[28],[30]

(1) When you buy garment?

Table:3

\begin{tabular}{|l|l|}
\hline Yearly & $2.50 \%$ \\
\hline Quarterly & $22.50 \%$ \\
\hline Seasons & $50 \%$ \\
\hline Occasionally & $25 \%$ \\
\hline
\end{tabular}

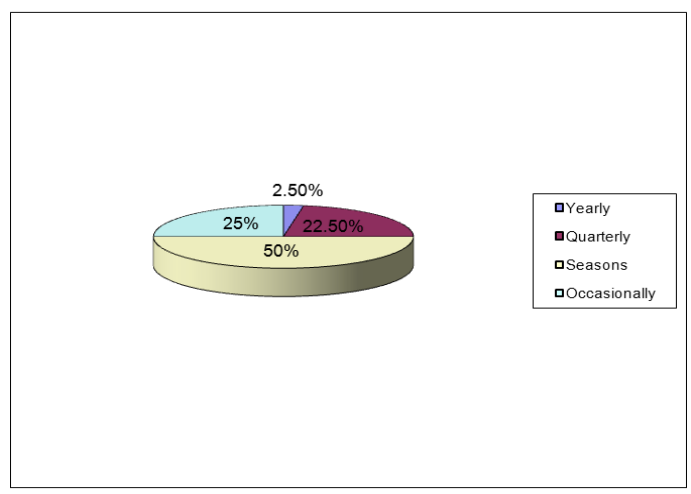

Fig:3

INTERPRETATION: Mostly the customer comfort to buy fabrics during festival season like Diwali marriage season or on sales

(1) What are the factors which are important while buying the garment?

Table:4

\begin{tabular}{|l|l|}
\hline Raymond's & $20 \%$ \\
\hline Siya ram & $35 \%$ \\
\hline Reid \& Taylor & $40 \%$ \\
\hline Rachna & $5 \%$ \\
\hline
\end{tabular}

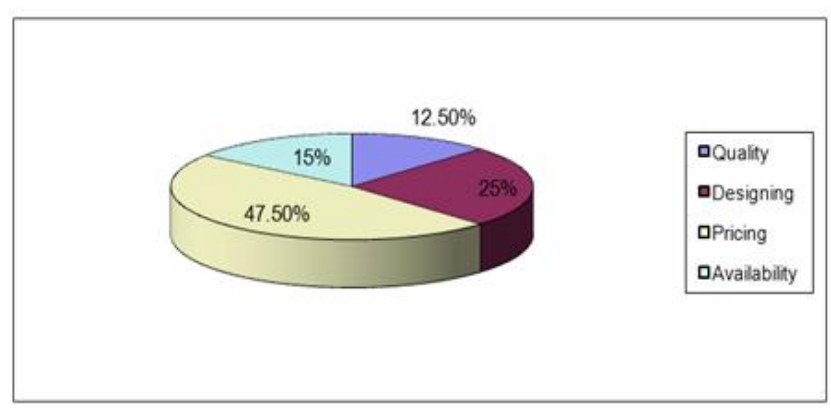

Fig:4
INTERPRETATION: The above data reveals that mostly people go to Reid \& Taylor.

(1) Which major improvement in RACHNA WOOLEN MILL would automatically stimulate to buy them? Table:5

\begin{tabular}{|l|l|}
\hline Quality & $12 \%$ \\
\hline Price & $16 \%$ \\
\hline Designing & $22 \%$ \\
\hline Advertisement & $50 \%$ \\
\hline
\end{tabular}

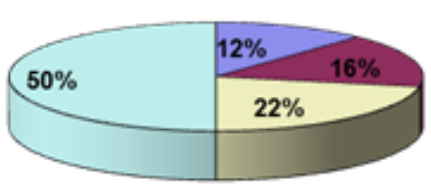

口Quality

口Price

口Designing

口Advertise

Fig:5

INTERPRETATION: Analysis of the above data reveals that the major improvement in RACHNA advertisement

(1) Does advertising influence your buying decision about Garment/Fabrics?

Table: 6

\begin{tabular}{|l|l|}
\hline YES & $70 \%$ \\
\hline NO & $30 \%$ \\
\hline
\end{tabular}

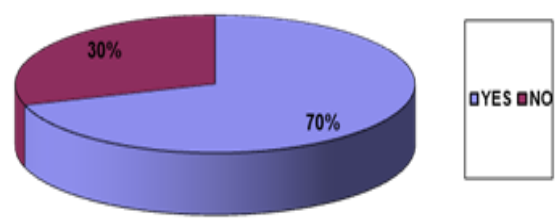

Fig: 6

INTERPRETATION:

$\mathbf{7 0} \%$ customer said advertising influence their buying decision and $30 \%$ customer said their buying decision not depend upon advertising.

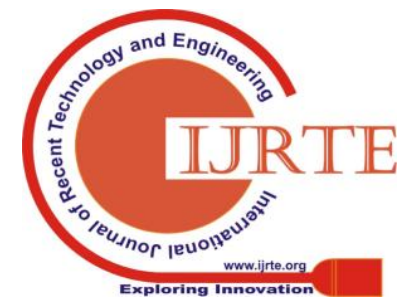


A Look at Wellknown Perception of Patron About Emblem Name and Advertising Technique and The Way It Impacts Their Buying Choice, at Rachna Woolen Mill, Ludhiana (Punjab)

\section{RESULTS}

Readymade clothes are greater favored than fabrics in clients.

Teenagers segment provide extra preference to the readymade garment than fabric garments/ fabrics in the main offered by way of client every so often.

- Kids segment is the frequent consumer of clothes.

- Retail store is the most desired region for buying garments /fabric.

- Mall and one-of-a-kind store are popular among kids.

- Logo name impacts the buying selection of the client.

- Advertising and marketing has splendid impact on the product sale.

- Television is the maximum famous media for advertising among patron. Newspaper, magazines and billboards also appeal to customer interest.

- Celebration attracts the consumer for the specific product.

- Price is the crucial factor at the same time as making buying choice. Availability of product is likewise the one of the aspect which affects shopping for decision.

- Clients are aware of emblem name RACHNA fabrics but they may be no longer a whole lot privy to its readymade garment logo REDA

- RACHNA fabric has impression of high best and reliable products inside the market.

- No with no trouble availability of RACHNA product is one in every of its drawbacks.

- Low income compared to market ability,

- Less advertisement of the product in comparison to other agency. encouragement \& motivation related to customer.

\section{DISCUSSION}

Corporation must reform its advertising strategies.

$\square$ Corporation may go for reposition its emblem picture.

$\square$ The product excellent ought to be advanced

$\checkmark$ Corporation have to put effort in growing sales by means of imparting presents and discounts.

$\square$ Organisation ought to makes techniques for rural market.

$\square$ As we understand that multi logo showrooms are greater popular within the semi city towns likes Phagwara, Jalandhar etc. so the agency should cognizance on strengthening the deliver chain a good way to make manufacturers available with maximum outlets.

$\checkmark$ RACHNA can open extra shops of its personal. Retailing is one of the growing sectors which give decent margins.

$\square$ Extra classified ads of their merchandise locally in addition to country wide level.

$\square$ Sponsoring the pupil's activities like technical pageant, management capabilities.

$\checkmark$ Rent superstar to propose the emblem.

$\square$ Survey should be undertaken every so often to have information approximately the developments inside the market
- There's a need of a proper statistics,

\section{CONCLUSION}

During my education, I was completely assisted via the management and the group of workers of RACHNA to carry out my project paintings. There is a good harmony, coordination and information between them that makes the jogging of the mill fairly green and smooth. concerning my project take a look at, I understand that there's a tremendous capability for institutional income inside the market and RACHNA is properly prepared to fulfill the call for concerning the exceptional and amount of GARMENT\&fabrics. [31],[33],[35]

RACHNA lacks exposure in cooperate quarter. Many human beings are prejudiced about the incorrect interest paid to the client at the mill. the relationship of the dealers with retailers isn't always wholesome. sellers do not pay attention to the proceedings by the shops. also a few court cases regarding the loss of life and color fastness were encountered during survey. The completing and durability of the RACHNA GARMENT became highly preferred[32]

\section{REFERENCES}

1. G BharthVajan R., Ramachandran S.,Psychographic dimensions of training,2016,International Journal of Pharmacy and Technology,V-8,I-4,P-23727-23729

2. Balakrishnan P., Bharthvajan R.,A study on human resource planning in hospitals in Chennai City,2014,International Journal of Applied Engineering Research,V-9,I-22,P-7503-7507

3. Priyadarsini P., Bharthvajan R.,Role of emotional intelligence training programme in reducing the stress of the nurses,2014,International Journal of Applied Engineering Research,V-9,I-22,P-7411-7421

4. Kerinab Beenu G., Bharthvajan R.,Empirical analysis on the cosmetic buying behavior of young women in South India,2014,International Journal of Applied Engineering Research,V-9,I-22,P-7361-7366

5. Balakrishnan P., Bharthvajan R.,Whistling in the wind,2014,International Journal of Applied Engineering Research,V-9,I-22,P-7586-7593

6. Krishnan B., Peter M.,Health hazards of Indian Bpo employee-an alarming issue,2014,International Journal of Applied Engineering Research,V-9,I-22,P-7336-7341

7. Kerinab Beenu G.H., Peter M.,Role of insurance in economic development,2014,International Journal of Applied Engineering Research,V-9,I-22,P-7532-7539

8. Balakrishnan P., Peter M., Priyadarsini P.,Efficiency of safety measures for wellbeing of employees in manufacturing industry,2014,International Journal of Applied Engineering Research,V-9,I-22,P-7376-7382

9. Anbarasi M., Praveen Kumar S.,Online sales promotions of herbal products and its effectiveness towards tanisha.com,2019,Indian Journal of Public Health Research and Development,V-10,I-1,P-195-200

10. Anbarasi M., Praveen Kumar S., Various online marketing and promotions strategies to improve the validation towards the organic products in the pharmaceutical sectors,2019,Indian Journal of Public Health Research and Development, V-10,I-1,P-263-269

11. Loganathan R., Praveen Kumar S.,Grievance handling a key factor for solving issues of employees in an organization,2014,International Journal of Applied Engineering Research,V-9,I-22,P-7483-7491

12. Loganathan R., Praveen Kumar S.,Study on preference of private label brands in super and Hypermarkets,2014,International Journal of Applied Engineering Research,V-9,I-22,P-7327-7335

13. Smitha M., Praveen Kumar S.,Understanding stress and its managementamong the nurses in Chennai city,2014,International Journal of Applied Engineering Research,V-9,I-22,P-7560-7565

14. Kerinab Beenu G.H., Praveen Kumar S.,A study on the investment behavior of Chennai investors in mutual fund schemes,2014,International Journal of Applied Engineering Research,V-9,I-22,P-7520-7525 
15. Loganathan R., Praveen Kumar S.,Retention strategies key for organizational productivity,2014,International Journal of Applied Engineering Research,V-9,I-22,P-7443-7447

16. Pavithra J., Ganesan M., Brindha G.,State wise analysis of microfinance sector in India,2016,International Journal of Pharmacy and Technology,V-8,I-4,P-23417-23432

17. Pavithra J., Ganesan M.,A comparative study on microfinance in India and abroad,2016,International Journal of Applied Business and Economic Research,V-14,I-8,P-5471-5476

18. Pavithra J., Ganesan M.,A study on awareness and impact of micro-financial schemes,2016,International Journal of Applied Business and Economic Research,V-14,I-8,P-5449-5460

19. Senthilmurugan P., Pavithra J.,Consumer preference towards organised retailing with reference to Big Bazaar,2014,International Journal of Applied Engineering Research,V-9,I-22,P-7469-7475

20. Senthilmurugan P., Pavithra J.,Implication of social media marketing in growing healthcare industry,2014,International Journal of Applied Engineering Research,V-9,I-22,P-7448-7456

21. Loganathan R., Pavithra J.,Consumer perception towards private label brand over other brands in super markets and hypermarkets,2014,International Journal of Applied Engineering Research,V-9,I-22,P-7355-7360

22. Kerinab Beenu G., Pavithra J.,Tradeâ€"off between liquidity and profitability in logistics industry,2014,International Journal of Applied Engineering Research,V-9,I-22,P-7398-7401

23. Kerinab Beenu G., Pavithra J.,A study on the prospective consumerâ€ $\mathrm{TM}_{\mathrm{S}}$ perception towards utility cars in Chennai city,2014,International Journal of Applied Engineering Research,V-9,I-22,P-7526-7531

24. Pavithra J., Dilli Babu P., Ambuli T.V.,A study on budgetary control at Maruti Service Masters, Chennai,2014,International Journal of Applied Business and Economic Research,V-12,I-2,P-151-161

25. Pavithra J., Dilli Babu P., Ambuli T.V.,A study on customer satisfaction of retro Garments Pvt Ltd, Chennai,2014,International Journal of Applied Business and Economic Research,V-12,I-2,P-381-391

26. Kerinab Beenu G.H., Pavithra J., Senthilmurugan P.,A study on the influence of promotional activities for TATA ARIA among consumers in Chennai,2014,International Journal of Applied Engineering Research,V-9,I-22,P-7572-7578

27. Vijayaragavan S.P.,An investigative expert that's general FBG sensors, International Journal of Mechanical Engineering and Technology,V-8,I-8,PP-1500-1505,Y-2017

28. Vijayaragavan S.P.,Equalization routing protocol for Wi-Fi sensor strategy,International Journal of Mechanical Engineering and Technology,V-8,I-8,PP-1662-1666,Y-2017

29. Karthik B., Kiran Kumar T.V.U., Vijayaragavan P., Bharath Kumaran E.,Design of a digital PLL using 0.35 $\hat{\mathrm{I}}^{1 / 4 \mathrm{~m}}$ CMOS technology,Middle East Journal of Scientific Research,V-18,I-12,PP-1803-1806,Y-2013

30. Kanniga E., Selvaramarathnam K., Sundararajan M.,Kandigital bike operating system,Middle - East Journal of Scientific Research,V

31. Jasmin M., Vigneshwaran T., Beulah Hemalatha S.,Design of power aware on chip embedded memory based FSM encoding in FPGA,International Journal of Applied Engineering Research,V-10,I-2,PP-4487-4496,Y-2015

32. Jasmin M.,Optimization techniques for low power VLSI circuits,Middle - East Journal of Scientific Research,V-20,I-9,PP-1082-1087,Y-2014

33. Jasmin M., Vigneswaran T.,Fuzzy controller for error control of on Chip communication,2017 International Conference on Algorithms, Methodology, Models and Applications in Emerging Technologies, ICAMMAET 2017,V-2017-January,I-,PP-1-5,Y-2017

\section{AUTHORS PROFILE}

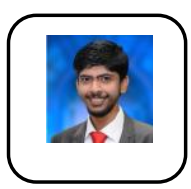

Gowtham Aasirvad Kumar Assistant Professor ,Department of MBA, Bharath Institute of Higher Education and Research, Tamilnadu, India

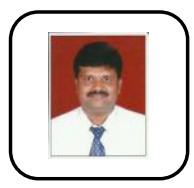

Dr.A.Ravikumar Associate Professor ,Department of THM, Bharath Institute of Higher Education and Research, Tamilnadu, India

D.Raviteja Student,Department of MBA, Bharath Institute of Higher Education and Research, Tamilnadu, India 